УДК 94 (477.46) «1905/1907»

DOI: https://doi.org/10.33782/eminak2019.2(26).291

\title{
СЕЛЯНСТВО УМАНСЬКОГО ПОВІТУ У РЕВОЛЮЦІЙНИХ ПОДІЯХ 1905-1907 pp.
}

\author{
Наталія Тацієнко \\ Уманський державний педагогічний університет імені Павла Тичини (Умань, Україна) \\ e-mail: tatsiyenko_natalia@ukr.net \\ ORCID: https://orcid.org/0000-0002-7872-9008
}

У статті аналізується участь селянства Уманського повіту у революційних подіях 1905-1907 рр. Наведено яскраві приклади селянських заворушень на Уманщині, а саме аграрні страйки сезонних сільськогосподарських робітників, основною вимогою яких було підвищення плати за щоденні роботи; напади на маєтки та їх підпали, що ставали звичним, масовим явищем; захоплення поміщицьких земель і лісу, з вимогами розділення цих земель між селянами; супротив владі. З'ясовано, що значну роль у протестних настроях селянства Уманського повіту відігравали прокламації, про що свідчать матеріали розслідувань.

Ключові слова: селянство, страйки, безземелля, підпали, прокламація, Уманський повіт

Селянський рух становив органічну складову революції 1905-1907 рр., адже за характером завдань, рушійною силою, масштабами супротиву революція була селянською. Соціальні очікування селян базувалися на завершенні аграрної революції, скасуванні викупних платежів, передачі землі у їх власність, розвитку товарного сільськогосподарського виробництва і т.д. Злиденне становище, накопичене невдоволення та гнів поступово набували руйнівних форм, а саме - захоплення поміщицьких земель, руйнування маєтків, підпали, страйки, супротив владі. Нагальною була зміна форм селянського землекористування, вивільнення робочих рук, створення ринків найманої праці, необхідних для індустріалізації економіки.

Участь селянства у революційних подіях початку ХХ ст. висвітлюється багатьма науковцями. Зокрема, В. Іванушкін ${ }^{1}$ розглядав передумови аграрних заворушень початку XX ст. на Київщині, розвиток страйкового та селянського рухів у регіоні, акцентуючи увагу на боротьбі за право на землю як споконвічному бажанні селян. А. Буцик ${ }^{2}$ характеризував селянські страйки як своєрідну форму бойкоту поміщика, з метою покращення умов праці та підвищення платні або отримання поступок у користуванні орендованою землею та пасовищами, а як максимум - можливість назавжди позбавитися влади землевласника. За підрахунками М. Лещенка ${ }^{3}$ та I. Реви ${ }^{4}$,

\footnotetext{
1 Іванушкін В. Селянський рух 1905-1906 р. на Київщині: економічні передумови, зміст та наслідки. Київ: Держвидавництво України, 1926. 100 с.; Іванушкін В. Економіка селянського руху 19051906 рр. на Київщині // Життя й революція. 1925. № 10. С. 81-86.

2 Буцик А. Селянський рух на Київщині в 1906 р. // Наукові записки КдУ ім. Т. Шевченка. 1955. T. XIV. Вип. 6. С. 19-44.; Буцык А. Крестьянское движение на Киевщине в революции 1905-1907 гг.: дис... канд. ист. наук. Київ, 1947. 276 с.

3 Лещенко М. Селянський рух на Правобережній Україні в період революції 1905-1907 рр. Київ: Вид-во АН УРСР, 1955. 231 с.

4 Рева І.М. Страйки селян і сільськогосподарських робітників Правобережної України (19051907 рр.) // Український історичний журнал. 1975. № 8. С. 37-44.
} 
селянські страйки на Правобережжі становили 3/5 від усіх виступів. Зокрема, навесні 1905 р. страйки на Київщині були головною формою протесту, складаючи 93\% від загальної кількості селянських виступів, а в цілому за 1905 р.- 69\%5. За підрахунками М. Лещенка, співвідношення активних страйків до пасивних можна представити як 4/5. Спочатку селяни вдавались до пасивного страйку і вже потім їхня боротьба набувала більш активних, наступальних форм ${ }^{6}$.

Монографія О. Михайлюка7 присвячена комплексному дослідженню змін, що відбулися у селянському середовищі періоду модернізаційних і революційних перетворень перших десятиліть ХХ ст. В. Соболє ${ }^{8}$ розглянув стосунки влади та селянської громади через призму діяльності військово-судових установ на прикладі Київського військово-окружного суду, як елементів каральної системи у період революції 19051907 рр. Детальний історіографічний огляд страйкового руху українського селянства на початку ХХ ст. здійснив Д. Кудінов ${ }^{9}$. Магась-Демидас ${ }^{10}$ розглядала зміну ставлення хліборобів Наддніпрянської України до влади у 1905 - лютому 1917 pр.

Метою даної публікації $є$ висвітлення трансформації ставлення селян Правобережної України, зокрема Уманського повіту, до революційних подій 1905-1907 pр.

До економічних причин селянських виступів можна віднести неврожайні роки на рубежі XIX-XX ст., мало- і безземелля селянства, котре несло на собі тягар викупних платежів архаїчних феодальних повинностей. Селяни самовільно рубали поміщицькі ліси, забирали реманент, сіно та збіжжя своїх поміщиків, вимагали знизити орендну плату, випасали худобу на поміщицьких пасовищах тощо. Найбільшої інтенсивності досягає рух на Правобережжі. 336 повітів Правобережної України селянськими заворушеннями були охоплені 23. Серед сезонних сільськогосподарських робітників поширюються аграрні страйки. Протягом весни-літа у цьому регіоні відбулося близько 500 виступів, які були добре організовані, відбувалися без кровопролиття, переважно мирними методами. Основною вимогою їх учасників було підвищення плати за щоденні роботи. Так, 19 травня 1905 р. на поля землевласника Георгія Ящика с. Хижна з'явилося понад 300 місцевих селян, хоча й напередодні прикажчиком було запрошено тільки 50 осіб з платою по 40 коп. у день. Всі 300 селян стали до роботи, яку закінчили до полудня, після чого пішли в економію за розрахунком, при чому вимагали для кожного робітника по 40 коп. Управителі маєтком Єфимій і Микола Ящики пропонували їм по 20 коп. з огляду на неповний робочий день і чисельність робітників. Але селяни стояли на своєму і з причини їх збудженого стану, за свідченнями Ящиків, вимогу було задоволено. Ящики у даному випадку швидше спрацювали на випередження, адже за свідченнями волосного старшини та поліцейського стражника, заворушень серед селян не помічалось, і в очікуванні заробітної плати вони спокійно сиділи у дворі економії.

Вранці наступного дня близько 30 місцевих знову з'явилися на полях Ящика та

\footnotetext{
5 Рева І.М. Вказ. праця. С. 39.

6 Лещенко М. Вказ. праця. С. 128-133.

7 Михайлюк О.В. Селянство України в перші десятиліття XX ст.: соціокультурні процеси. Дніпропетровськ: Інновація, 2007. 456 с.

8 Соболєв В. Справи про селянські заворушення в практиці Київського військово-окружного суду // Етнічна історія народів Європи. 2009. Вип. 28. С. 140-145.

${ }^{9}$ Кудінов Д.В. Страйковий рух Наддніпрянської України у 1900 - лютому 1917 роках: історіографія проблеми. Суми: Папірус, 2014. 352 с.

10 Магась-Демидас Ю. Трансформація ставлення селянства Наддніпрянської України до влади (1905 - лютий 1917 рр.) // Емінак: науковий щоквартальник. 2016. № 2 (14). С. 22-27.
} 
стали переконувати працюючих там підлітків залишити роботу до тих пір, доки поміщик не буде платити їм по рублю в день, причому, деякі з прибулих погрожували побиттям тим, хто відмовлявся. Роботи на полях було припинено, робітники прийшли до економії, вимагали платню за повний робочий день, пояснюючи, що припинили роботу не за власним бажанням. Але Ящики відмовилися, після чого хтось із робітників розбив камінням вікно, інший кинув сапу в Григорія, а селянка Марія Коцюбова вдарила сапою Миколу Ящика. Того ж дня селяни с. Хижна з'явилися на полях поміщика Журавського та заявили йому, що відтепер «по Маніфесту» він повинен платити робітникам по рублю в день.

Вранці 1 червня уже в с. Корсунка на буряковій плантації землевласника Євгенія Журавського з'явилися до 80 осіб корсунських селян, які чи то внаслідок умовлянь, чи то силою, вигнали робітників із сусіднього с. Павлівки. У той же день ввечері натовп селян, підбурений Феодосієм Рижаниковим, Мокієм Гайдою, Семеном Дядькуном, прийшли в економію з вимогою збільшити платню вдвічі, але отримали відмоBy.

У той самий день селяни с. Павлівки з'явилися на буряковій плантації ферми «Марцеліни» Євгенія Журавського при с. Майданецькому. Погрожуючи побиттям, вони стали вимагати припинення робіт. Робітники приєдналися до натовпу та відправилися у двір ферми, де вимагали від управителя економією дворянина Владислава Павловського платні, погрожуючи йому, але нанесли побої тільки помічнику управителя Піонтковському. Останній, злякавшись, відіслав за касиром Кульчицьким, а сам з поліцейським та охоронцем зачинився у конторі. До прибулого касира зверталися з вимогою грошей і ті, кого не було на плантації. 3 метою недопущення фізичної розправи вимоги задовольнили, після чого натовп розійшовся з вигуками «да здравствует республика, восьмигодинний робочий день, да здравствует социалдемократическая партия»11.

3 жовтня 1905 р. форми боротьби стають активнішими. Напади на маєтки та їх підпали стають звичним, масовим явищем, що супроводжували селянські виступи. Типовою стала така картина: вдень дороги переповнювались екіпажами поміщиків, котрі тікали до міст, а вночі стояла заграва від численних пожеж і погромів. Драматичні події в українському селі на початку XX ст. яскраво зображено у повісті М. Коцюбинського «Fata Morgana», де автор вже у назві твору намагався показати примарність надій і сподівань селянства на землю, волю, ліквідацію соціальної нерівності.

Протягом 1905 р. в Київській губернії сталося 2469 пожеж, з яких - 136 у містах і 2333 у повітах. Причинами у 582 випадках, тобто у 24\% від загальної кількості, названі саме підпали ${ }^{12}$. Такою ж тенденція залишалася і наступного 1906 р. (22,3\%), протягом якого в губернії сталося 2748 пожеж, з яких - 194 в містах і 2554 в повітах, у результаті яких згоріло 4165 дворів. Сума збитків становила 5441435 руб. (876 148 руб. у містах і 4565287 руб. у повітах) ${ }^{13}$. Кількість пожеж у 1907 р. збільшилась порівняно з 1906 р. на 26,6\%, кількість згорілих будинків - на 29,9\%, сума ж

11 Центральний державний історичний архів України у м. Києві (ЦДІАК України). Ф. 317. Оп. 1. Спр. 4429. Арк. 1-2.

12 Памятная книжка Киевской губернии на 1907 год. Киев: Киевская Губернская Типография, 1906. C. 119.

13 Памятная книжка Киевской губернии на 1908 год с приложением адрес-календаря губернии. Киев: Типо-Литография Губернского Правления, 1908. С. 191. 
збитків навпаки зменшилася на 20,2\%. Кількість навмисне спричинених пожеж теж зросла порівняно з минулим роком: якщо у 1906 р. це було 614 випадків, то 1907 р. 791 (22,7\%)14. Про те, що події 1905-1907 рр. були апогеєм невдоволення селян, наслідком конфлікту поміщицького та селянського світосприйняття, свідчать факти поступового загострення ситуації. Для прикладу, в с. Поташ Уманського повіту 12 січня 1903 р. о 18 годині згоріла скирта соломи орендного власника, дворянина Дравановського, завдавши збитків на суму в 500 руб. Потерпілий підозрював у підпалі селянина Василія Мачуського, який неодноразово погрожував йому15.

На Київщині поширювалася чутка про царський указ, за яким поміщицьку землю треба розділити між селянами, але поміщики, не бажаючи його реалізації, ховають указ від селянства. Про популярність такої думки свідчить і той факт, що ідея справедливого розподілу землі звучала навіть у церкві. Так, священик с. Бабанка Уманського повіту Олекса Казанський у свойй проповіді 21 листопада 1905 р. говорив, що всі заколоти у Росії через неправильний розподіл землі серед народу. А між тим, наприклад, у Франції поміщик мав всього 100 дес., коли ж у Російській імперії поміщики багатії, що мали по кілька тисяч десятин землі. Священик наголошував, що навіть духовенство уже відмовилося від земельних наділів. А ще, що за ті заколоти, що вже сталися, велика провина падала на уряд через неправдиві розпорядження. Випадки таких розмов були далеко непоодинокими, що свідчило про співчутливе ставлення духовенства до селянського становища ${ }^{16}$.

Ці та безліч подібних випадків показують як з численних невирішених аграрних протиріч виростав ланцюг вимог, що створювали сприятливий грунт для селянських заворушень. Однією з ознак зріючого соціального вибуху було зменшення селянського попиту на поміщицьку землю. Селяни утримувались від купівлі поміщицької землі та сподівались, що та перейде селянству без грошей. Про це зазначав київський губернатор у своєму листі до міністра внутрішніх справ ${ }^{17}$. Очікуючи розподілу землі, селянство надзвичайно вороже ставилося до сторонніх претендентів на поміщицькі угіддя. Так, селяни с. Харківки Уманського повіту звернулися до мирового посередника з вимогою про те, щоб виселити з їхнього села всіх сторонніх людей, які служили у поміщика. На думку селян, це було необхідним з огляду на те, щоб ці люди не отримали землі, яка, ніби то, навесні мала перейти їм від поміщика18.

Причини селянських заворушень були досить різноманітними. Каталізатором початку селянських заворушень часто ставали усілякі чутки, що підсилювалися агітаційною літературою та різного роду прокламаціями. Протести селян с. Майданецького Уманського повіту, що закінчилися розгромами двох заводів, були спричинені чутками про те, що місцевий священик Маковецький на з'їзді місцевих землевласників у м. Умань 3 приводу значення аграрного питання в їх місцевості, висловив думку, що у майданецьких селян землі загалом достатньо, і взагалі діяв проти їхніх інтересів, підтримуючи інтереси панів. А також селяни вірили, що можуть збільшити свої земельні наділи за рахунок землі приватних землевласників. Тому близько опівночі 27 грудня 1905 р. до цукрового заводу економії Журавського

\footnotetext{
14 Памятная книжка Киевской губернии на 1909 год с приложением адрес-календаря губернии. Киев: Типо-Литография Губернского Правления, 1909. С. 193.

15 ЦДІАК України. Ф. 442. Оп. 633. Спр. 2. Ч. 1. Арк. 23.

16 Іванушкін В. Селянський рух 1905-1906 р. на Київщині... С. 42.

17 Там само. С. 44.

18 Там само. С. 46.
} 
підійшов натовп місцевих селян, які не пускали робітників, що йшли на нічну зміну. Решта ввірвалися на завод, i, вигнавши звідти всіх майстрів та робітників, зупинили виробництво. Прибулий поліцейський був осипаний лайкою та стусанами, а тому втік. А натовп, дізнавшись, що священик знаходиться неподалік підприємства у будинку бухгалтера заводу Краузе, з криками рушив туди. Змусивши священика вийти до них, лаючись і штовхаючись, селяни вимагали від нього пояснень щодо уманського з'їзду, при чому, не дивлячись на вмовляння священика, потягли його льодом через ставок до його квартири, а потім до сільської школи, де переляканий і побитий священик, боячись за своє життя заявляв, що в усьому стояв за них і що пани навіть погрожували йому.

Вдосвіта 28 грудня юрба, що збільшилася до декількох сотень, раптово рушила на дамбу ставка, де були розміщені сільськогосподарська майстерня економії, винокурний завод і квартири робітників. Дехто камінням почав громити вікна та двері заводу, а інші вдерлися у майстерню та порозбивали усі сільськогосподарські машини. Частину ж машин та екіпажів, складених поблизу майстерні, кинули у ставок. 0 6-7-й годині ранку в приміщенні винокурного заводу були розбиті машини й апарати заводу, із погребів було украдено до 100 відер спирту19. Постраждали й квартири службовців заводу. Мешканці зі страху втікали, а все їх майно було частково розграбоване, а частково знищене. У квартирі хіміка Хехловського були розбиті письмовий стіл, крісла, піаніно та розірвані матраци. Підійшовши до квартири директора, селяни вимагали викуп, за невчинення погрому, за що отримали 5 руб. Загалом збитки погрому винокурного заводу склали 16-18 тис. рублів.

Розбивши винокурний завод, натовп повернувся до цукрового заводу. Спроби директора та декількох робітників поговорити з юрбою нічого не дали. Розпочавши з повного розгрому заводської контори та каси, звідки селяни вкрали гроші, вони громили і сам завод, і квартири працівників. Машини й устаткування були зіпсовані так, що працювати далі без капітального ремонту завод не міг. Було украдено, здебільшого жінками та дітьми, 600 пудів цукрового піску та 30 мішків по 6,5 пудів кожен розфасованого цукру. До 3 години погроми завершилися, частина погромників розійшлася додому, а частина, зокрема жінки, тягли мішки з цукром. Та, побачивши загін драгунів, вони кидали ношу і тікали до села. У ході проведених поліцією обшуків, частину заводського та приватного майна службовців знайшли у селянських хатах. Настрій селян підігрівали чутки про те, що «якщо не розбивати заводів, то і землі не дадуть», або, що вийшов такий закон, «що і в батька рідного можна землю відібрати». Як зазначає В. Соболєв, характерною особливістю селянських судових процесів даного періоду був досить високий відсоток виправданих, який, у значній мірі, досягався за рахунок справ із великою чисельністю фігурантів.

Терміни ув'язнення за справами про селянські заворушення були різними у діапазоні від 2 місяців до 3,5 років ${ }^{20}$. Наприклад, у Майданецькій справі із 60 селян під слідство потрапили 20 осіб (за даними В. Соболєва - 27), а в якості звинувачених опинилися 18. Інші говорили, що участі не брали, а просто спостерігали. Лише 43 них отримали покарання, термін якого на 2 місяці перевищував визначене судом мінімальне покарання. Причини такої лояльності, з одного боку, можна пояснити «особливим» ставленням до селянина як суб'єкта злочину, а з іншого, необхідно від-

\footnotetext{
19 ЦДІАК України. Ф. 315. Оп. 4. Спр. 47. Арк. 2.

20 Соболєв В. Вказ. праця. С. 143.
} 
значити вкрай недосконалий судово-слідчий механізм. Щодо першого, то у деяких справах про поширення селянами агітаційних листівок Київська судова палата пом'якшувала вироки або ж взагалі закривала справи, оскільки судді вважали, що підсудні селяни були наскільки темними, що не розуміли значення написаного. Такий самий підхід був й у представників революційного табору. Адже часто адресовані до селян прокламації нагадували скоріше казки з повчальним змістом, аніж зразки революційної агітації. На деяких звернутих до селян прокламаціях Революційної української партії, як заохочення до прочитання, зазначалося: «Хто буде це читати, буде золоті мигдалі получати» та «як будуть люди ці листки читати, то не будуть пани і цар панувати»21.

В якості пом'якшувальних обставин могли вказуватися легковажність, перебування в стані алкогольного сп'яніння, слабоумство і т.п. Так у протоколі майданецького сільського сходу від 11 січня 1906 р. вказано, що всі злочинні дії здійснено переважно молоддю, що пояснювалося ії легковажністю. Вражає рішення сільського сходу с. Майданецького, в якому селяни просили вислати з села 20 осіб, яких вважали головними винуватцями заворушень і взагалі, особливо небезпечними елементами, від яких можна очікувати й інших злочинних дій. Цей документ зачитувався у ході процесу як важливий для розуміння ходу справи аргумент. При чому в ході судового слідства було виявлено, що до частини зазначених осіб обвинувачення винесено безпідставно 22 .

У зверненні київського губернатора до селян Київської губернії йшлося про тяжкі випробування, які породили всезагальне незадоволення. Зазначалося, що царська турбота перш за все звернена дійсно на потреби селянства, що доводить Маніфест від 3 листопада, яким імператор наказав зменшити з наступного року викупні платежі на половину і зовсім скасувати їх з 1907 р., також розширити діяльність Селянського банку для полегшення купівлі землі малоземельним і безземельним селянством. «Крестьянам нужна и дорога земля, но нельзя добивать ее путем насилия. ...Государственная Дума, где крестьянские представители несомненно будут в большинстве ...и каждый желающий трудится на земле будет иметь к тому законный и честный путь»23.

У зверненні землевласників Правобережної України до Київського, Подільського і Волинського генерал-губернатора зазначалося, що серед інших причин такого настрою селянства потрібно виділити агітацію серед селян революційних елементів, які поширювали прокламації винятково анархічного змісту. Однак не лише прокламації, а й деякі газети теж переконували, що дії уряду злочинні і що доки вони не встануть самі зі зброєю у руках, їх потреби не будуть задоволені, а «правительство только обещает все, а ничего не делает». До таких видань належали «Начало» та «Новая жизнь», які не приховували своєї агітації серед військових і селян. Спрямування даних видань можна зрозуміти із деяких заголовків: «Смерть помещикам», «Умрите вовремя (помещики)», «Аграрная революция растет» і т.п. У зверненні до генерал-губернатора зазначалось, що сприянню у викупі селяни не надавали великого значення, так як між ними давно поширені чутки, що буде розподіл землі спершу державної, удільної, а потім і приватної 24.

\footnotetext{
21 Там само. С. 143.

22 ЦДІАК України. Ф. 315. Оп. 4. Спр. 47. Арк. 3-4.

${ }^{23}$ ЦДІАК України. Ф. 442. Оп. 704. Спр. 349. Арк. 4-5.

24 ЦДІАК України. Ф. 442. Оп. 704. Спр. 349. Арк. 12-17.
} 
Попри те, що згадуваний вище прокламаційний вплив дійсно був, зокрема і в Уманському повіті, свідчать матеріали слідства по звинуваченню селян С.Ф.Білоуса та Є.Є. Македона у поширенні в с. Корсунка Уманського повіту нелегальних листівок «Української громади»25; прокламація революційного змісту надрукована українською мовою під заголовками «Селяни-хлібороби» та «Солдатська пам'ятка»; а також справа по звинуваченню дворянина Григорія Жилинського, де йшлося про поширення прокламації злочинного змісту серед селян Київської губернії (прокламації партії «Земля і воля», «Слово тайного братства «Земля і воля» до всіх добрих людей»)26.

Із матеріалів справ про державні злочини, що відклалися у жандармських управліннях за 1886 р. відомо про те, що 14 листопада в м. Умань виявлені розклеєні на ліхтарних стовпах 5 екземплярів записок у вигляді віршів «с высшей степени дерзкими выражениями о Священной особе Государя Императора». Місцева поліція підозрювала у даних діях рядового в запасі, колишнього вчителя 2-го Одеського єврейського училища Абрама Райхтейна, який перебував на особливому контролі27.

Під особливим наглядом поліції, жандармських управлінь перебували вчителі та студенти. Так, вчителя 1 класу Маньківського двокласного училища Євгенія Подольського запідозрено у політичній неблагонадійності, в результаті чого його ув'язнено в Уманській тюрмі. І це незважаючи на те, що під час обшуку в його квартирі не знайшли ніяких доказів даного звинувачення. За перебування під слідством Подольського було звільнено з місця роботи, хоча й не було доведено його причетність та вину в цьому злочині. До того ж, він ніколи не перебував на контролі поліції й отримав позитивні рекомендації від волосного правління Бердичівського повіту, де працював у Белилівському училищі 28 . Також із справи звинувачення учня Київської семінарії Олександра Ковальського в агітації селян с. Майданецького Уманського повіту щодо захоплення поміщицьких земель відомо, що справу закрито за відсутності доказів, так як одна розмова не дає підстав вбачати у ній пропаганду. Було встановлено, що Олександр лише один раз говорив зі сторожем заводу Клименком у присутності селянина Іщенка про те, що за чутками передбачається наділити селянам по 5,5 десятин землі. А на питання, де візьмуть землю, відповів: «А у Журавського (местного помещика) мало-ли земли у одного, всем жить надо - ему же Бог дал... что если бы всем за дело взяться, то было-бы хорошо»29.

Селяни-делегати від Уманського повіту, які брали участь 21 грудня 1905 р. у засіданні Київського Центрального губернського комітету, представляли 16 волостей, по 2 делегати від кожної (лише від Верхняцької - 1 делегат, а від Інаньківської - 3). У своїх заявах делегати піднімали багато наболілих питань, зокрема про освіту, наголошуючи на потребі нових шкіл, після завершення яких найбільш здібні учні мали б право здобувати освіту у вищих навчальних закладах за державний кошт. Делегат від Кузьмінської волості Юхим Мельник скаржився, що не всі селяни його волості отримали земельні наділи. Заробітку майже не було, так як на цукрових заводах працював порівняно незначний відсоток селян. Крім того, поміщики за безцінок пропонували роботу селянам з інших сіл. Оренда землі зависока - 30 руб. за десяти-

\footnotetext{
25 ЦДІАК України. Ф. 274. Оп. 1. Спр. 1295. Арк. 21.

26 ЦДІАК України. Ф. 442. Оп. 831. Спр. 74. Арк. 1-2.

27 ЦДІАК України. Ф. 301. Оп. 1. Спр. 143. Арк. 5.

${ }^{28}$ ЦДІАК України. Ф. 707. Оп. 225. Спр. 11. Арк. 3-5.

29 ЦДІАК України. Ф. 317. Оп. 1. Спр. 3625. Арк. 9.
}

Eminak, 2019, 2 (26) 
ну, тому селяни пропонували встановити їі розмір не більше 10 руб. Були двори, на які припадало не більше $1 / 8$ десятин землі. Селяни просили виділити землю або з поміщицької - за плату, або ж - з державної. Якщо не вистачатиме, деякі селяни згодні були навіть на переселення. Наголошувалося на потребі покращення освітнього рівня, оскільки при тодішньому стані училищ народ залишався темним. Пропонували відкривати двокласні училища, де б, крім основної програми, дітей навчали б ремеслу. Представники від Маньківської волості підкреслювали: «А то народ остается темним и всяк его надувает».

Також більшість говорили про потребу навчати не лише грамоті, а й ремеслу, як зазначали представники Тальнівської волості, знаючи яке «можно проживать безбедно». Микита Плохотнюк і Юстин Галушка зазначали, що церковні школи були малоефективними, тому потрібні міністерські школи і хоча б по одному на волость сільськогосподарському і ремісничому навчальному закладу ${ }^{30}$.

Суди, на думку деяких делегатів, потрібно ліквідувати, зокрема волосні, бо їхні рішення були несправедливими, адже «за могарич всегда можна купить судей», тому й виникла потреба у створення нового всестанового суду. Селяни зазначали, що їм не потрібні ні урядники, ні справники, а лише селянське управління.

Піднімалося й питання церковної землі, яку селяни одноголосно пропонували забрати у священиків, так як вони отримували з неї значні прибутки (у Тальнівській волості за десятину під буряк беруть 35 руб.). «Церковная земля должна принадлежать церкви, а не священнику, который должен существовать на жалование», - заявляли делегати з Бабанської волості 31 .

Поряд з цими, все ж основним питанням було наділення селян землею та завищена ціна при купівлі, адже вона коливалася від 400 до 550 руб. за десятину, а «это ярмо на шею крестьянину, хотя бы их и выдал полностью крестьянский банк»32. Говорили і про непосильність оренди, адже плата тут коливалася від 25 руб. у Хижнянській і Підвисоцькій волостях до 40-50 руб. у Русалівській волості. Прохор Тихолоз 3 Русалівської волості теж нарікав на малоземелля: у нього сім'я складалася з 11 осіб, а тому земельного наділу не вистачало навіть для забезпечення елементарних продовольчих потреб. Усі делегати говорили про вплив євреїв на завищення ціни на оренду землі. Економія віддавала землю по 7-13 руб., але до селян вона доходили через треті, а то й четверті руки.

Тобто так чи інакше, але основним спірним питанням була земля. У більшості скарг і позовів селян рішення виносились не на їх користь, часто прохання визнавалися безпідставними або й взагалі до розгляду не приймалися. Причини позовів до суду були різними, як врешті, і кривдники селян. Так, з червня 1907 р. по липень 1914 р. відбулося 479 селянських виступів, з них 323 (67,4\%) - на Правобережжі. За ознакою причин їх можна представити такими групами: на випаси та незаконні викоси припадало 137 випадків, 39 - підпали, 37 - страйки, 31 - протести проти обмежень оренди, сервітутних прав, 25 - вирубка поміщицьких лісів, 25 - опір столипінській реформі тощо ${ }^{33}$.

Отже, найпотужнішою силою революції було селянство. Селянський революційний рух був досить автономним: селяни керувалися власними інтересами, викорис-

\footnotetext{
30 ЦДІАК України. Ф. 442. Оп. 704. Спр. 349. Арк. 20.

31 ЦДІАК України. Ф. 442. Оп. 704. Спр. 349. Арк. 20-21.

32 ЦДІАК України. Ф. 442. Оп. 704. Спр. 349. Арк. 22.

33 Історія селянства Української РСР. Т. 1. Київ: Наукова думка, 1967. С. 503.
} 
товуючи свої засоби боротьби (підпали, захоплення поміщицьких земель, страйки, протистояння поліції та військам). Поряд з традиційними формами протесту селяни використовували нові - сільські страйки. Страйковий рух сільськогосподарських робітників був найпотужнішим саме на Правобережжі. Селянські страйки були відповіддю на жахливі умови життя і праці, брак засобів до існування найчисельнішої верстви населення.

\section{REFERENCES}

Butsyk, A. (1947). Krestianskoe dvizhenie na Kievshchine v revoliutsii 1905-1907 gg. [Peasant movement in Kyiv region during the revolution of 1905-1907]. (Candidate's thesis). Kyiv [in Russian].

Butsyk, A. (1955). Selianskyi rukh na Kyivshchyni v 1906 r. [Peasant movement in Kyiv region in 1906]. Naukovi zapysky KDU imeni T. Shevchenka, XIV, 6, 19-44 [in Ukrainian].

Ivanushkin, V. (1925). Ekonomika selianskoho rukhu 1905-1906 rr. na Kyivshchyni [The peasant movement economy in Kyiv region in 1905-1906]. Zhyttia i revoliutsiia, 10, 81-86 [in Ukrainian].

Ivanushkin, V. (1926). Selianskyi rukh 1905-1906 r. na Kyivshchyni: ekonomichni peredumovy, zmist ta naslidky [Peasant movement in 1905-1906 in Kyiv region: economic conditions, content and consequences]. Kyiv: Derzhvydavnytstvo Ukrainy [in Ukrainian].

Kudinov, D.V. (2014). Straikovyi rukh Naddniprianskoi Ukrainy u 1900 - liutomu 1917 rokakh: istoriohrafiia problemy [Strike movement on Ukrainian territories above Dnipro River in 1900 February 1917: historiography of the issue]. Sumy: Papirus [in Ukrainian].

Leshchenko, M. (1955). Selianskyi rukh na Pravoberezhnii Ukraini v period revoliutsii 1905-1907 rr. [Peasant movement on the Right-Bank Ukraine during the revolution of 1905-1907]. Kyiv [in Ukrainian].

Mahas-Demydas, Yu. (2016). Transformatsiia stavlennia selianstva Naddniprianskoi Ukrainy do vlady (1905 - liutyi $1917 \mathrm{rr}$.) [Transformation of peasantry attitudes to authorities on Ukrainian territories above Dnipro River (1905 - February 1917)]. Eminak: naukovyi shchokvartalnyk, 2 (14), 22-27 [in Ukrainian].

Mykhailiuk, O.V. (2007). Selianstvo Ukrainy $v$ pershi desiatylittia 20 st: Sotsiokulturni protsesy [Peasantry of Ukraine in the first decades of the $20^{\text {th }}$ century: social and cultural processes]. Dnipropetrovsk: Innovatsiia [in Ukrainian].

Reva, I.M. (1975). Straiky selian i silskohospodarskykh robitnykiv Pravoberezhnoi Ukrainy (19051907 rr.) [Strikes of peasants and agricultural workers on the Right-Bank Ukraine (1905-1907)]. Ukrainskyi istorychnyi zhurnal, 8, 37-44 [in Ukrainian].

Soboliev, V. (2009). Spravy pro selianski zavorushennia v praktytsi Kyivskoho viiskovo-okruzhnoho sudu [Cases of peasant riots in the practices of Kyiv military court]. Etnichna istoriia narodiv Evropy, 28, 140-145 [in Ukrainian].

Istoriia selianstva Ukrainskoi RSR (1967). [The history of the peasantry in the Ukrainian SSR]. T. 1. Kyiv [in Ukrainian].

\section{Nataliya Tatsiyenko}

(Pavlo Tychyna Uman State Pedagogical University, Uman, Ukraine)

ORCID: https://orcid.org/0000-0002-7872-9008

\section{The Peasantry of Uman County in the Revolutionary Events of 1905-1907}

The participation of Uman county peasantry in the revolutionary events of 1905-1907 is analyzed in the paper. Striking examples of peasant unrest in Uman region are presented, namely, agrarian strikes of seasonal agricultural workers, the main requirement of which was the increase of the payment for daily work; attacks on the estates and their arson, which became a common, mass occurrence; seizure of landowners' estates and forests, with requirements for sharing of those lands among peasants; resistance to authorities.

A decrease in the peasant's demand for land purchase in the hope of obtaining it for free is indicated. It is noted that the catalyst of peasant unrest often became all kinds of rumors heightening with propaganda literature. As an example, the protests of Maidanetske village 
residents are described, which were provoked by rumors about the unreliability of the local priest's words at the meeting of landowners and ended with wreck and ruin of two plants. The «special» attitude towards the peasant as a subject of crime is stressed. From the materials of the investigations, it has been revealed that a prominent role in the peasantry protest mood in Uman county was played by proclamations.

The author examines the appeals of the peasants-delegates of Uman county to Kyiv Provincial Board, which raised questions about scanty land plots, church lands, overpricing of land rent and purchase, injustice and inactivity of the judicial system, education, etc. It is stated that for the peasants the main controversial issue was the land, and the confirmation of which there was a huge number of complaints and claims, the dispositions of which were mostly not in their favor, the appeals were found to be baseless or were not taken cognizance at all.

Keywords: peasantry, strikes, lack of land, arsons, proclamation, Uman county 